\title{
Occurrence and release of cadmium, chromium, and lead from stone coal combustion
}

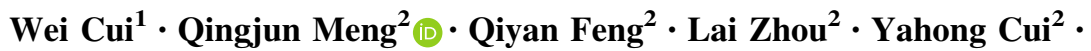 \\ Wenbo $\mathbf{L i}^{2}$
}

Received: 5 August 2019/Revised: 7 October 2019/Accepted: 30 October 2019/Published online: 12 November 2019

(C) The Author(s) 2019

\begin{abstract}
Stone coal, which has high ash yield, low carbon content, and low calorific value, releases toxic elements during the combustion process. In this study, samples were collected from an open-pit stone coal mine in the southern Shaanxi province, China. A simulated combustion experiment and sequential chemical extraction were applied to investigate the enrichment, occurrence, and release of $\mathrm{Cr}, \mathrm{Cd}$, and $\mathrm{Pb}$ in raw stone coal and ash. The contents of $\mathrm{Cr}, \mathrm{Cd}$, and $\mathrm{Pb}$ in raw stone coal were larger than those reported for other coals in China and worldwide. The enrichment factors of $\mathrm{Cr}, \mathrm{Cd}$, and $\mathrm{Pb}$ in ash at different temperatures exceeded 0.7, with the exception of $\mathrm{Cd}$ at $1000{ }^{\circ} \mathrm{C}$. This indicates that $\mathrm{Cr}, \mathrm{Cd}$, and $\mathrm{Pb}$ were first enriched at low temperature (below $600{ }^{\circ} \mathrm{C}$ ) and then volatilized at high temperature due to the decomposition of clay minerals. The dominant forms of toxic elements in raw stone coal were $\mathrm{Fe}-\mathrm{Mn}$-bound $\mathrm{Cr}$ and $\mathrm{Cd}$ and carbonates of $\mathrm{Pb}$. As the temperature increased, the organic forms decreased obviously, and the residual forms increased; however, the $\mathrm{Fe}-$ Mn-bound forms remained the dominant forms of $\mathrm{Cr}, \mathrm{Cd}$, and $\mathrm{Pb}$.
\end{abstract}

Keywords Stone coal $\cdot$ Occurrence and release $\cdot$ Combustion $\cdot$ Cadmium $\cdot$ Chromium $\cdot$ Lead

\section{Introduction}

Coal, as the major energy, bears certain microelements which are beneficial or harmful. Stone coal is an inferior type of anthracite with high ash content, low carbon content, and low calorific value; stone coal is also a low-grade polymetallic symbiotic ore (Cheng 2001). Stone coal is formed by the saprofication and coalification of living organisms such as bacteria, algae, and other organisms in shallow seas, lagoons, and bays. China has abundant stone coal resources totaling $618.8 \times 10^{8} \mathrm{t}$, which are mainly distributed in the middle and lower reaches of the Yangtze River in Hunan, Hubei, Anhui, Jiangxi, Zhejiang, Shaanxi,

Qingjun Meng

qjmeng930@126.com

1 Shaanxi Huacheng Industrial Joint Stock Company, Xi'an, Shaanxi, China

2 School of Environmental Science and Spatial Informatics, China University of Mining and Technology, Xuzhou, China and other provinces. Among them, the South Qinling District has the most abundant reserves and the highest coal quality. Stone coal contains trace elements such as $\mathrm{U}$, As, $\mathrm{Pb}, \mathrm{Zn}, \mathrm{Cu}, \mathrm{Mn}, \mathrm{Cd}, \mathrm{Se}, \mathrm{P}$, and $\mathrm{Cr}$, some of which have value for extraction and recycling (Du et al. 2017).

The use of cheap stone coal in power plants can effectively alleviate shortages of power supply in remote areas. Furthermore, the high contents of minerals such as quartz and kaolinites in stone coal can be applied to produce cement, brick, and other building materials. As a lowcalorific energy source, stone coal is developed and utilized in areas where coal resources are relatively scarce. This saves high-quality coal resources and promotes local economic development (Liu et al. 2016a, b; Chu and Zhang 2014; Li et al. 2005).

Coal is a composite mixture containing trace elements such as $\mathrm{Hg}, \mathrm{Se}, \mathrm{Pb}, \mathrm{Cr}, \mathrm{Cd}$, and $\mathrm{Mn}$. During the combustion of coal, the trace elements in coal are redistributed through complex physicochemical changes. Nonvolatile elements (e.g., $\mathrm{Ba}$ and $\mathrm{Sn}$ ) are not volatilized during combustion and are uniformly distributed in the fly ash and bottom slag 
produced by combustion. Volatile condensing elements (e.g., $\mathrm{As}, \mathrm{Pb}, \mathrm{Cr}$, and $\mathrm{Cd}$ ) are enriched in the fine fly ash. Some or all of the volatilization during the combustion process along with physical and chemical changes (e.g., homogeneous nucleation and heterogeneous condensation) occur after the coal enters a lower-temperature environment. Volatile noncondensing elements (e.g., $\mathrm{Hg}$ and $\mathrm{Se}$ ) in the unobvious enrichment of fly ash are emitted to the atmosphere in gaseous form (Swaine and Goodarzi 1995).

The $\mathrm{Pb}$ contents of the World coal were reported to range from 0.1 to $7900 \mu \mathrm{g} / \mathrm{g}$, with the contents in most coal samples being $2-80 \mu \mathrm{g} / \mathrm{g}$ (Yao et al. 2002). Bai (2003) analyzed 1018 coal samples from China and reported lead contents ranging from 0 to $93.5 \mu \mathrm{g} / \mathrm{g}$ with an average of $17.68 \mu \mathrm{g} / \mathrm{g}$. Numerous studies have shown that lead in coal is mainly found in the form of sulfides (e.g., galena and pyrite) (Swaine 2013; Finkelman 2005; Zhang et al. 2000), leading to chemical reactions under high-temperature and reducing conditions. During the process of separating lead and sulfur into simple substances or oxides, if the temperature does not reach the condition where the gas-phase metal or its oxide is stable, lead chloride is easily produced (Wen and Xu 2010; Xu 2004; Uberoi and Shadman 1990). To study the changes in the chemical forms of trace elements during coal combustion, the possible chemical forms of the trace elements and their distributions were predicted based on the chemical equilibrium as the temperature increased from 400 to $2000 \mathrm{~K}$ (Yu et al. 2004). The results indicated that the volatility of trace elements during coal combustion increased in the following order: $\mathrm{Cd}<\mathrm{Pb}<$ $\mathrm{Cr}$. The forms of heavy metals in different types of coal varied widely, and the presence of organic materials enhanced the heavy metal volatility. Therefore, the volatility of $\mathrm{Pb}, \mathrm{Cd}$, and $\mathrm{Cr}$ should be determined by the type of coal and its occurrence (Chen et al. 2001). Shi and $\mathrm{Wu}$ (2016) reported that the volatility of heavy metals is proportional to the combustion temperature.

While the occurrence of coal has been widely studied, few studies have evaluated the environmental geochemistry of toxic elements contained in stone coal and its combustion ash. In particular, the occurrence and release of toxic elements during combustion are poorly understood. Because of the composition of stone coal and the diverse forms of different elements, basic systematic research on the occurrence, speciation, and associated minerals of heavy metals in raw stone coal and its ash products under different combustion conditions is needed. The results of such studies would be useful to understand the transformation of toxic elements during stone coal combustion.

\section{Materials and methods}

\subsection{Sampling}

Coal samples were collected from an open-pit stone coal mine in Haoping river basin, Ankang City, Shaanxi Province, China. The stone coal-bearing rock structure is a Cambrian and Silurian series of Marine sedimentary black rock. The main coal-bearing stratum in the area is the late Ordovician and early Silurian Jiaguguan formation $\left(\left(\mathrm{O}_{3}-\right.\right.$ $S_{1}$ ) b) (Jia 2014). Representative test samples were obtained by mixing four raw coal samples. The stone coal samples were stored immediately in sealed plastic bags to prevent contamination and weathering. After being transported to the laboratory, the stone coal samples were airdried, crushed, pulverized, and passed through a 200-mesh sieve for analysis.

\subsection{Proximate analysis}

Proximate analysis $\left(M_{\mathrm{ad}}, A_{\mathrm{d}}, V_{\mathrm{daf}}\right.$, and $\left.F_{\mathrm{Cd}}\right)$ of the stone coal samples was performed according to Chinese coal standard GB/T212-2008, which is comparable to ASTM standards (ASTM-D3173-11, 2011; ASTM-D3174-11, 2011; and ASTM-D3175-11, 2011). The total sulfur content and contents of different forms of sulfur were measured using a WS-S101 automatic sulfur analyzer according to Chinese standards GB/T 214-2007 (equivalent to ASTM standard D3177-02, 2002) and GB/T 215-2003 (equivalent to ASTM standard D2492-02, 2012), respectively.

\subsection{Stimulated combustion experiment}

Stimulated combustion experiments were carried out in a muffle furnace. Six combustion temperature points were chosen between 500 and $1000{ }^{\circ} \mathrm{C}$ in $100{ }^{\circ} \mathrm{C}$ intervals to study the occurrence and release behavior of trace elements $(\mathrm{Cr}, \mathrm{Cd}$, and $\mathrm{Pb})$ during stone coal combustion. Each crucible contained approximately $2 \mathrm{~g}$ of stone coal sample. The crucibles were placed into the muffle furnace for burning and ashing. After reaching the set temperature, the crucible was warmed for $4 \mathrm{~h}$. The burned coal samples were then removed from the muffle furnace and cooled to room temperature in a dryer. The following notations were used to identify the raw and heated coal samples: HS (experimental raw stone coal), HS5 (coal ash burning at $500{ }^{\circ} \mathrm{C}$ ), HS6 (coal ash burning at $600{ }^{\circ} \mathrm{C}$ ), HS7 (coal ash burning at $700{ }^{\circ} \mathrm{C}$ ), HS8 (coal ash burning at $800^{\circ} \mathrm{C}$ ), HS9 (coal ash burning at $900{ }^{\circ} \mathrm{C}$ ), and HS10 (coal ash burning at $\left.1000{ }^{\circ} \mathrm{C}\right)$. 


\subsection{Elemental analysis}

Approximately $0.1 \mathrm{~g}$ of raw stone coal (burned for $3.5 \mathrm{~h}$ at $450{ }^{\circ} \mathrm{C}$ to remove carbon and increase digestion efficiency) and the burned stone coal samples were digested with $8 \mathrm{ml}$ $\mathrm{HNO}_{3}, 2 \mathrm{ml} \mathrm{H}_{2} \mathrm{O}_{2}, 3 \mathrm{ml} \mathrm{HF}$, and $4 \mathrm{ml} \mathrm{HClO}_{4}$ in Teflon digestion vessels. The samples were then gradually heated on a hot plate from 100 to $210{ }^{\circ} \mathrm{C}$ for $12 \mathrm{~h}$. After cooling, the digested solutions were diluted to $25 \mathrm{ml}$ with $5 \%$ $\mathrm{HNO}_{3}$. The total concentrations of $\mathrm{Cd}, \mathrm{Cr}$, and $\mathrm{Pb}$ were determined by inductively coupled plasma mass spectroscopy (ICP-MS; Thermo Fisher Scientific). The accuracy of the determination was evaluated using a standard coal reference material (SARM20). The instrument was calibrated using multi-elemental standard solutions containing known concentrations of $\mathrm{Cr}, \mathrm{Cd}$, and $\mathrm{Pb}$. The calibration curves for all three elements were linear $\left(R^{2}>0.999, n=6\right)$ over the studied concentration range. The precision for each of these elements was within $\pm 5 \%$.

\subsection{Sequential chemical extraction of heavy metals}

According to the method of Tessier et al. (1979), the five forms which are exchangeable, carbonates, Fe-Mn oxides, organic matter, and residual forms of raw stone coal and the stone coal samples heated at $600{ }^{\circ} \mathrm{C}$ and $1000{ }^{\circ} \mathrm{C}$ were surveyed as follows. The sample $(1 \mathrm{~g})$ was added to a 50-ml plastic centrifugation tube. After adding $8 \mathrm{ml}$ of $1 \mathrm{~mol} / \mathrm{l} \mathrm{MgCl} 2 \cdot 6 \mathrm{H}_{2} \mathrm{O}$, the contents of the tube were oscillated for $1 \mathrm{~h}$ at $200 \mathrm{rpm}$ at $25{ }^{\circ} \mathrm{C}$ and then centrifuged for $10 \mathrm{~min}$ at $4000 \mathrm{rpm}$. The supernatant was completely removed and filtered to determine the exchangeable forms. Then, the residue was extracted by $\mathrm{NaAc}(\mathrm{pH}=5.0)$ at room temperature, oscillated for $8 \mathrm{~h}(200 \mathrm{rpm})$, and centrifuged for $10 \mathrm{~min}$ at $4000 \mathrm{rpm}$. The supernatant was filtered to analyze carbonate-bound forms. The above residue was sequentially extracted by adding $20 \mathrm{ml} 25 \%$ (v/v) acetic acid (HAC) solution and $0.04 \mathrm{~mol} / \mathrm{l}$ hydroxylamine hydrochloride $\left(\mathrm{NH}_{2} \mathrm{OH} \cdot \mathrm{HCl}\right)$ followed by oscillation for $4 \mathrm{~h}$ at $96{ }^{\circ} \mathrm{C} \pm 3{ }^{\circ} \mathrm{C}$. The supernatant was centrifuged for $10 \mathrm{~min}$ at $4000 \mathrm{rpm}$, removed, and filtered to determine the forms of $\mathrm{Cr}, \mathrm{Cd}$, and $\mathrm{Pb}$ bound to $\mathrm{Fe}-\mathrm{Mn}$ oxides. $\mathrm{HNO}_{3}$ ( $3 \mathrm{ml}, 0.02 \mathrm{~mol} / \mathrm{l}$ ) and $5 \mathrm{ml} \mathrm{30 \%} \mathrm{(v/v)} \mathrm{H}_{2} \mathrm{O}_{2}$ were added to the above residue. The mixture was then heated at $85^{\circ} \mathrm{C}$ in a water bath for $2 \mathrm{~h}$. After adding $5 \mathrm{ml} \mathrm{H}_{2} \mathrm{O}_{2}$, the mixture was further heated at $85{ }^{\circ} \mathrm{C} \pm 2{ }^{\circ} \mathrm{C}$ for $3 \mathrm{~h}$. The solution $\mathrm{pH}$ oscillated intermittently during extraction and was adjusted to 2 with $\mathrm{HNO}_{3}$. After cooling the extracted solution, $5 \mathrm{ml} \mathrm{NH} \mathrm{NH}_{4} \mathrm{Ac}(3.2 \mathrm{~mol} / \mathrm{l})$ was added, and the solution was diluted to $20 \mathrm{ml}$ with $20 \%$ (v/v) $\mathrm{HNO}_{3}$ followed by continual oscillation for $30 \mathrm{~min}$ and centrifugation for $10 \mathrm{~min}$ at $4000 \mathrm{rpm}$. The supernatant was removed and filtered to determine the organic forms of $\mathrm{Cr}, \mathrm{Cd}$, and
$\mathrm{Pb}$. After extracting the organic forms, the residue was digested using the same method as for raw coal samples, coal ash samples extracted by $\mathrm{HNO}_{3}-\mathrm{HF}-\mathrm{HClO}_{4}$. All the extracted solutions were analyzed by ICP-MS using the same instrument conditions as for the analysis of raw stone coal samples.

\subsection{Mineralogy and microstructure of stone coal and its ash}

The mineral compositions of stone coal and heated stone coal ash were determined by X-ray diffraction (XRD; Panalytical X'Pert 3 Power). XRD patterns were recorded over a $2 \theta$ interval of $10^{\circ}-70^{\circ}$ with a step increase of $0.01^{\circ}$. The minerals were demarcated in terms of the International Centre For Diffraction Data (ICDD) powder diffraction files. The morphologies of raw stone coal and its ash were observed by scanning electron microscopy (SEM; Carl Zeiss SIGMA).

\subsection{Data manipulation}

The arithmetic means were used for all parameters. Pairwise comparison between means were made with independent-sample $T$ tests at the confidence level of 0.05. Data analysis and equation fitting were performed using SPSS and Origin software.

\section{Results and discussion}

\subsection{Proximate and ultimate analysis of raw stone coal}

Table 1 shows the results of proximate and ultimate analyses of experimental raw coal. The raw stone coal contained $2.40 \%$ moisture, $39.16 \%$ ash, $4.87 \%$ volatile matter, and $53.57 \%$ fixed carbon. The calorific value was $5.53 \mathrm{MJ} /$ $\mathrm{kg}$, much lower than that of standard coal $(290 \mathrm{MJ} / \mathrm{kg})$. Pyrite was the primary form of sulfur, accounting for $96.7 \%$ of total sulfur. The raw stone coal was characterized by high ash yield, medium sulfur content, low moisture content, low volatile matter content, and low calorific value according to Chinese coal classification standards (MT/T 850-2000, GB/T 15224.1, MT/T 849, GB/T 15224.2, and $\mathrm{GB} / \mathrm{T}$ 15224.3).

\subsection{Occurrence of $\mathrm{Cr}, \mathrm{Cd}$, and $\mathrm{Pb}$ in stone coal}

The stone coal mine in Haoping is situated in southern Shaanxi, and the samples collected belong to the ZiyangZhenping stone coal belt in southern Qinling. Over 60 elements are found in Chinese stone coal, including Se, V, 
Table 1 Proximate and ultimate analysis of a raw stone coal sample

\begin{tabular}{lllllllll}
\hline$M_{\mathrm{ad}}(\mathrm{wt} \%)$ & $A_{\mathrm{d}}(\%)$ & $V_{\mathrm{daf}}(\mathrm{wt} \%)$ & $F C_{\mathrm{d}}(\mathrm{wt} \%)$ & $S_{\mathrm{t}, \mathrm{d}}(\mathrm{wt} \%)$ & $S_{\mathrm{s}, \mathrm{d}}(\mathrm{wt} \%)$ & $S_{\mathrm{p}, \mathrm{d}}(\mathrm{wt} \%)$ & $S_{\mathrm{o}, \mathrm{d}}(\mathrm{wt} \%)$ & $Q_{\mathrm{gr}, \mathrm{ad}}(\mathrm{MJ} / \mathrm{kg})$ \\
\hline 2.40 & 39.16 & 4.87 & 53.57 & 1.82 & 0.03 & 1.76 & 0.03 & 5.53 \\
\hline
\end{tabular}

Notes air dry basis; d: dry; daf: dry ash free; M: moisture; A: ash yield; V: volatile matter; FC: fixed carbon; St,d: total sulfur; Sp,d: pyritic sulfur; Ss,d: sulfate sulfur; So,d: organic sulfur; $\mathrm{Q}_{\mathrm{gr}, \mathrm{ad}}$ : the gross calorific value of air drying base

Table 2 Average contents of $\mathrm{Cr}, \mathrm{Cd}$, and $\mathrm{Pb}$ in raw stone coal from different regions in China (Dai et al. 2012; Ketris and Yudovich 2009; Chen et al. 2013; Luo et al. 1995; Liu 1984)

\begin{tabular}{lllll}
\hline Regions & $\mathrm{Cr}(\mu \mathrm{g} / \mathrm{g})$ & $\mathrm{Cd}(\mu \mathrm{g} / \mathrm{g})$ & $\mathrm{Pb}(\mu \mathrm{g} / \mathrm{g})$ & References \\
\hline Stone coal, China & & & & \\
$\quad$ Enshi, Hubei & 1000 & 27.5 & - & Chen et al. (2013), Mao et al. (1999) \\
Danjiang, Henan & 55 & 1.0 & 15 & Luo et al. (1995) \\
Ziyang, Shaanxi & 168 & 20.0 & 39 & Luo et al. (1995) \\
Pingli, Shaanxi & 224 & 1.0 & 27 & Luo et al. (1995) \\
Langao, Shaanxi & 306 & 200 & 56 & Luo et al. (1995) \\
Zhengping, Shaanxi & 164 & 3.55 & 97 & Du et al. (2017) \\
Haoping, Shaanxi & 121 & 0.2 & 40.6 & This study \\
Average value in earth crust & 110 & 0.22 & 12 & Liu (1984) \\
World coal & 16 & 0.25 & 7.8 & Ketris and Yudovich (2009), Dai et al. (2012) \\
China coal & 15.4 & 15.1 & Ketris and Yudovich (2009), Dai et al. (2012) \\
\hline
\end{tabular}

$\mathrm{Cr}, \mathrm{Ni}, \mathrm{Cd}, \mathrm{Pb}, \mathrm{Cu}, \mathrm{Ga}$, and $\mathrm{As}$ (Du et al. 2017). The contents of $\mathrm{Cr}, \mathrm{Cd}$, and $\mathrm{Pb}$ in stone coal in some regions of China are listed in Table 2. The contents of $\mathrm{Cr}, \mathrm{Cd}$, and $\mathrm{Pb}$ in stone coal vary largely by area, with particularly large variations observed for $\mathrm{Cr}$ and $\mathrm{Cd}$. The $\mathrm{Cr}, \mathrm{Cd}$, and $\mathrm{Pb}$ contents of stone coal in China are generally higher than the average values for world coal, Chinese coal, and the earth's crust. For the stone coal samples from the Haoping open-pit mine analyzed in this study, the mean contents of $\mathrm{Cr}, \mathrm{Cd}$, and $\mathrm{Pb}$ were $121,3.55$, and $40.6 \mu \mathrm{g} / \mathrm{g}$, respectively. According to the Standards of the Coal Industry of the People's Republic of China (MT/T 964-2005), these values indicate that the stone coal belongs to high- $\mathrm{Cr}\left(\mathrm{H}_{\mathrm{Cr}}\right)$, high$\mathrm{Cd}\left(\mathrm{H}_{\mathrm{Cd}}\right)$, and high- $\mathrm{Pb}\left(\mathrm{H}_{\mathrm{Pb}}\right)$ coal. Furthermore, the contents of $\mathrm{Cr}, \mathrm{Cd}$, and $\mathrm{Pb}$ in raw stone coal in this study were 7.9, 14.2, and 2.7 times that of Chinese coal (Dai et al. 2012) and 7.6, 16.1, and 5.2 times that of World coal (Ketris and Yudovich 2009), respectively. Compared to stone coal from other mines in Shaanxi, the $\mathrm{Cr}$ content in the stone coal from Haoping was lower, while the contents of $\mathrm{Cd}$ and $\mathrm{Pb}$ were higher. This indicates that the elemental contents might differ greatly between mines even when the coal-bearing strata are the same.

\subsection{Enrichment of $\mathrm{Cr}, \mathrm{Cd}$, and $\mathrm{Pb}$ in stone coal under different combustion temperatures}

The elemental contents in heated coal samples depend on two processes during combustion: enrichment and volatilization (Dai et al. 2017; Wang et al. 2013). The relative enrichment factors (EFs) are normally used to assess the degree of enrichment and volatilization. According to definition of the mass loss ratio of elements, the EF is expressed as follows (Liu et al. 2003; Mei 1994):

$\mathrm{EF}=X a \times \eta / X c$,

where $X a$ is the ash-based content of element $X$ in the heated coal, $X c$ is the content of element $X$ in raw coal; and $\eta$ is the corresponding ash yield per mass unit at the temperature of interest. The EF value is generally between 0 and 1, with a large EF indicating high enrichment and low volatility.

The ash yield gradually increases with increasing combustion temperature. To effectively compare the enrichment characteristics of samples heated to different temperatures, the ash-based contents of elements in the heated coal samples should be converted to total coal-based contents. The total coal-based element contents in the heated coal samples were determined as the products of $\mathrm{Xa}$ and $\eta$.

The EF values of the stone coal samples heated at temperatures ranging from 500 to $1000{ }^{\circ} \mathrm{C}$ are presented in 
Table 3 Contents and $\mathrm{EFs}$ of $\mathrm{Cr}, \mathrm{Cd}$, and $\mathrm{Pb}$ in raw stone coal and ash samples

\begin{tabular}{|c|c|c|c|c|c|c|c|}
\hline Coal sample & $\eta(\%)$ & $\mathrm{Cr}(\mu \mathrm{g} / \mathrm{g})$ & EFs & $\mathrm{Cd}(\mu \mathrm{g} / \mathrm{g})$ & EFs & $\mathrm{Pb}(\mu \mathrm{g} / \mathrm{g})$ & EFs \\
\hline HS & 39.16 & 121 & - & 3.55 & - & 40.6 & - \\
\hline HS5 & 41.16 & 228 & 0.78 & 6.93 & 0.80 & 82.2 & 0.83 \\
\hline HS6 & 39.74 & 299 & 0.95 & 6.47 & 0.83 & 89.7 & 0.88 \\
\hline HS7 & 34.9 & 321 & 0.93 & 9.02 & 0.89 & 108 & 0.93 \\
\hline HS8 & 35.29 & 301 & 0.88 & 8.94 & 0.89 & 108 & 0.94 \\
\hline HS9 & 33.79 & 314 & 0.88 & 8.42 & 0.80 & 107 & 0.89 \\
\hline HS10 & 27.79 & 323 & 0.74 & 6.45 & 0.50 & 107 & 0.73 \\
\hline
\end{tabular}

Notes $\eta$ is the corresponding ash yield per mass unit at the temperature of interest; ash-based content of elemental contents the heated coal samples refers to the total coal-based content

Table 3. The EFs of $\mathrm{Cr}, \mathrm{Cd}$, and $\mathrm{Pb}$ first increased and then decreased slightly with increasing combustion temperature from 500 to $1000{ }^{\circ} \mathrm{C}$. The rapid increase in EFs, especially for $\mathrm{Cr}$, can be attributed to the decomposition of lowvolatile components as the temperature increased from 500 to $600{ }^{\circ} \mathrm{C}$. As the temperature increased further to $700{ }^{\circ} \mathrm{C}$ and $800{ }^{\circ} \mathrm{C}$, the EF gradually decreased. When the temperature reached $1000{ }^{\circ} \mathrm{C}$, the EFs of $\mathrm{Cr}, \mathrm{Cd}$, and $\mathrm{Pb}$ were $0.74,0.50$, and 0.73 , respectively. These results differ from those of previous studies suggesting that the EFs of $\mathrm{Co}, \mathrm{Cr}$, $\mathrm{Ni}$, and $\mathrm{V}$ all decreased as the combustion temperature increased from 100 to $1200{ }^{\circ} \mathrm{C}$ (Tang et al. 2018; Li et al. 2018)

The EFs of $\mathrm{Cr}, \mathrm{Cd}$, and $\mathrm{Pb}$ in stone coal ash heated at 500-900 ${ }^{\circ} \mathrm{C}$ were greater than 0.8 , indicating relatively low $\mathrm{Cr}, \mathrm{Cd}$, and $\mathrm{Pb}$ volatilization. At the high temperature of $1000{ }^{\circ} \mathrm{C}$, the melting of clay minerals such as kaolinite and illite may have resulted in the release of heavy metals. Compared to $\mathrm{Cr}$ and $\mathrm{Pb}$, the EF of $\mathrm{Cd}$ was slightly lower at each combustion temperature, indicating the greater volatilization of $\mathrm{Cd}$ compared to $\mathrm{Cr}$ and $\mathrm{Pb}$. Swaine and Goodarzi (1995) speculated that organic matter is the main factor driving the increase in the EFs of low-volatile elements at relatively low temperatures $\left(500{ }^{\circ} \mathrm{C}\right.$ and $\left.700{ }^{\circ} \mathrm{C}\right)$. As the temperature increased from 700 to $1000{ }^{\circ} \mathrm{C}$ in this study, the $\mathrm{EFs}$ of $\mathrm{Cr}, \mathrm{Cd}$, and $\mathrm{Pb}$ in stone coal ash decreased slowly due to the decomposition of inert minerals such as silicates (Tang et al. 2018).

\subsection{Volatilization of $\mathrm{Cr}, \mathrm{Cd}$, and $\mathrm{Pb}$ in stone coal under different combustion temperatures}

The volatilization ratio $(V r)$ was used to further investigate the enrichment of $\mathrm{Cr}, \mathrm{Cd}$, and $\mathrm{Pb}$ during coal combustion. $V r$ was calculated as follows (Liu et al. 2016a, b):

$V r=(1-\mathrm{EF}) \times 100 \%$.

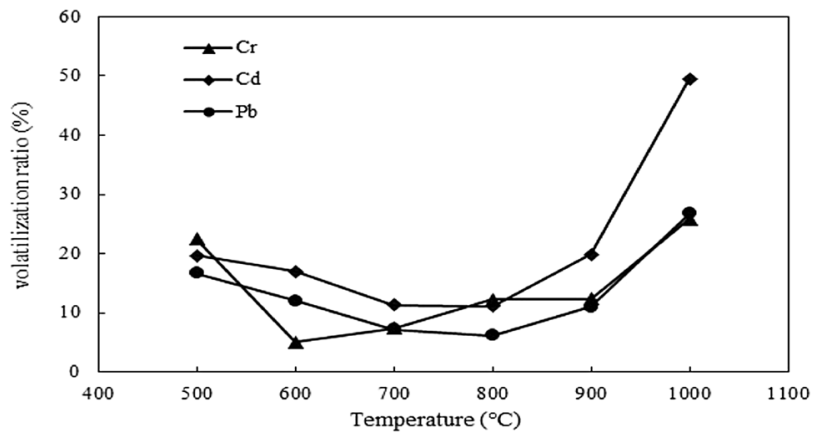

Fig. 1 Volatilization ratios of $\mathrm{Cr}, \mathrm{Cd}$, and $\mathrm{Pb}$ in stone coal under different combustion temperatures

As shown in Fig. 1, the $V r$ values of $\mathrm{Cr}, \mathrm{Cd}$, and $\mathrm{Pb}$ first decreased and then increased with increasing combustion temperature, opposite to the trend observed in the $\mathrm{EF}$ values. At low combustion temperature, the decrease in $\mathrm{Vr}$ and increase in EF may be due to the decomposition of organic matter and loss of water from stone coal. As the temperature increased further, the EFs gradually decreased, while $\mathrm{Vr}$ increased. At the combustion temperature of $1000{ }^{\circ} \mathrm{C}$, the $\mathrm{Vr}$ values of $\mathrm{Cr}, \mathrm{Cd}$, and $\mathrm{Pb}$ were $26 \%, 50 \%$, and $27 \%$, respectively, indicating that the high temperature increased the volatilization of the heavy metals and $\mathrm{Cd}$ in particular. However, the volatile contents of $\mathrm{Cr}$ and $\mathrm{Pb}$ were still relatively low, accounting for only approximately one quarter of the total $\mathrm{Cr}$ and $\mathrm{Pb}$ content in raw stone coal. This further demonstrates that $\mathrm{Cr}, \mathrm{Cd}$, and $\mathrm{Pb}$ are lowvolatile elements.

\subsection{Mineral compositions and microstructures of stone coal after combustion}

To further explore the enrichment and volatilization of $\mathrm{Cr}$, $\mathrm{Cd}$, and $\mathrm{Pb}$ in stone coal during combustion, the mineral compositions and microstructures of the stone coal samples were characterized by XRD and SEM. Table 4 shows the 
Table 4 Minerals in raw stone coal and ash samples (\%)

\begin{tabular}{lllllr}
\hline Samples & Quartz & $\begin{array}{l}\text { Potassium } \\
\text { feldspar }\end{array}$ & Plagioclase & Hematite & TCCM \\
\hline HS & 62.0 & 13.0 & 11.0 & - & 14.0 \\
HS6 & 60.0 & 16.0 & 14.0 & 3.0 & 7.0 \\
HS10 & 67.0 & 17.0 & - & 15.0 & 1.0 \\
\hline
\end{tabular}

$T C C M$ total clay minerals, mainly referring to kaolinites, dickites, and illites

mineral compositions of raw stone coal samples and coal ash heated to $600{ }^{\circ} \mathrm{C}$ and $1000{ }^{\circ} \mathrm{C}$. The minerals in raw coal were dominated by quartz, clay minerals (kaolinite, dickite, and illite), potassium feldspar, and plagioclase. As the combustion temperature increased, the fractions of clay minerals and plagioclase decreased, the fraction of hematite $\left(\mathrm{Fe}_{2} \mathrm{O}_{3}\right)$ significantly increased, and the fraction of quartz $\left(\mathrm{SiO}_{2}\right)$ increased slightly. Upon heating, the hydroxyl $(-\mathrm{OH})$ groups in the lattice were dehydrated, corresponding to the observed endothermic process. When the combustion temperature reached $600{ }^{\circ} \mathrm{C}$, kaolinite, a dioctahedral layered aluminosilicate, was dehydrated to form meta-kaolinite, a semi-amorphous intermediate phase (Vassileva and Vassilev 2006; Vassilev et al. 1992, 2005). When the combustion temperature reached $1000{ }^{\circ} \mathrm{C}$, the illites were initially dehydrated and then formed a glass phase at $950{ }^{\circ} \mathrm{C}$ followed by the final generation of silicon spinel, hematite, quartz, and other minerals (Tang et al. 2018). In this study, when stone coal was heated at high temperature, the $\mathrm{Al}$ in plagioclase might have been replaced by Fe, and hematite was formed during the process of mineral restructuring. The main mineral phase was reformed quartz, which was consistently present in both the raw and heated coal samples (Table 4 and Figs. 2 and 3) (Erarslan and Örgün 2017; Vassileva and Vassilev 2006). Similar results have also reported in other studies on coal

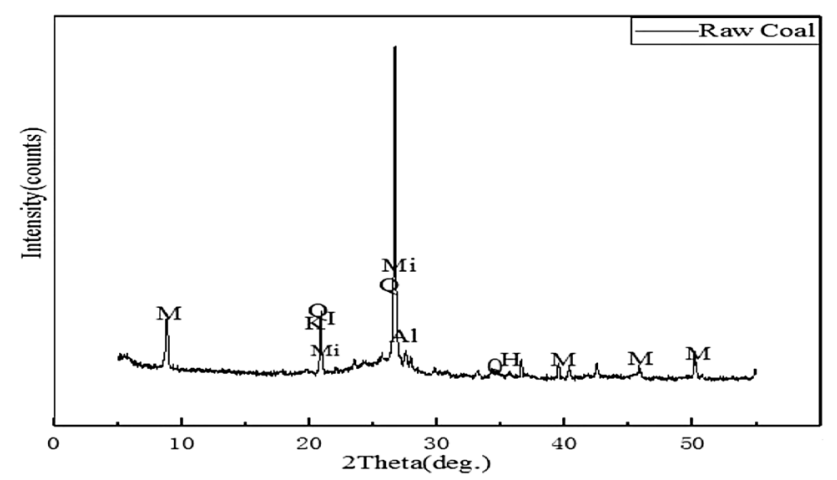

Fig. 2 XRD spectrum of raw stone coal. The minerals identified are: $H$ hematite, $I$ illite, $K$ kaolinite, $M$ muscovite, $M i$ microcline, $Q$ quartz, $A l$ albite transformation (Cutruneo et al. 2014; Martinello et al. 2014; Oliveira et al. 2014; Saikia et al. 2014; Silva et al. $2009 \mathrm{a}, \mathrm{b})$. When the combustion temperature reached $1000{ }^{\circ} \mathrm{C}$, the mineral phases tended to be simple and included primarily amorphous glass phases along with hematite and quartz.

As for aluminosilicates, the decomposition of clay minerals in stone coal resulted in the release of $\mathrm{Cr}, \mathrm{Cd}$, and $\mathrm{Pb}$ from the clay minerals during combustion (Fig. $2 \mathrm{~b}, \mathrm{c}$ ). The changes in the contents of low-volatile $\mathrm{Cr}, \mathrm{Cd}$, and $\mathrm{Pb}$ in stone coal ash depended on two aspects: releasing from the organic matter at low temperature and the clay minerals at high temperature. These results verify that volatile elements such as $\mathrm{As}, \mathrm{Pb}, \mathrm{Cr}$, and $\mathrm{Cd}$ are easily enriched in fine fly ash after combustion (Swaine and Goodarzi 1995).

\subsection{Release of $\mathrm{Cr}$, $\mathrm{Cd}$, and $\mathrm{Pb}$ from stone coal during combustion}

To explore the migration of elements during coal combustion, the chemical species in raw coal and coal ash heated to $600{ }^{\circ} \mathrm{C}$ and $1000{ }^{\circ} \mathrm{C}$ were determined. The forms of $\mathrm{Cr}, \mathrm{Cd}$, and $\mathrm{Pb}$ in stone coal and its combustion products produced at $600{ }^{\circ} \mathrm{C}$ and $1000{ }^{\circ} \mathrm{C}$ are shown in Fig. 4. Five forms of heavy metals were determined by sequential chemical extraction: exchangeable, carbonates, Fe-Mn oxides, organic matter, and residual forms.

The dominant form of $\mathrm{Cr}$ in raw stone coal was $\mathrm{Fe}-\mathrm{Mn}$ bound $\mathrm{Cr}$, accounting for $59 \%$ of total $\mathrm{Cr}$, followed by organic-bound $\mathrm{Cr}$, accounting for $24 \%$ of total $\mathrm{Cr}$, similar to the findings of a previous study (Gentzis and Goodarzi 2000). However, the fractions of different forms of $\mathrm{Cr}$ differed significantly by sample (Xiong et al. 2017). Most $\mathrm{Cr}$ in coal exists bound to organic matter (Robert et al. 2018) or as residual $\mathrm{Cr}$ ( $\mathrm{Li}$ et al. 2018). In coal ash, the major forms of $\mathrm{Cr}$ were carbonates and $\mathrm{Fe}-\mathrm{Mn}$-bound $\mathrm{Cr}$ (accounting for slightly more than $25 \%$ of total $\mathrm{Cr}$ ) at $600{ }^{\circ} \mathrm{C}$, and organic-bound $\mathrm{Cr}$ (accounting for $32 \%$ of total $\mathrm{Cr})$ at $1000{ }^{\circ} \mathrm{C}$. As the combustion temperature increased, the residual fraction of $\mathrm{Cr}$ gradually increased. Unlike the organic fraction of $\mathrm{Cr}$, the exchangeable and carbonatebound forms of $\mathrm{Cr}$ first increased and then decreased with increasing combustion temperature. This indicates that the burning of stone coal affected the forms of elements in the coal. During coal combustion, the internal energy of the molecules in coal increases, and the elemental activity increases due to the increase in temperature. The trace elements may be separated from the original molecules and recombined and redistributed in different combustion products. Trace elements in coal, which are found in the form of minerals, elements, and chelates, will differentiate at the beginning of combustion and continue to be 


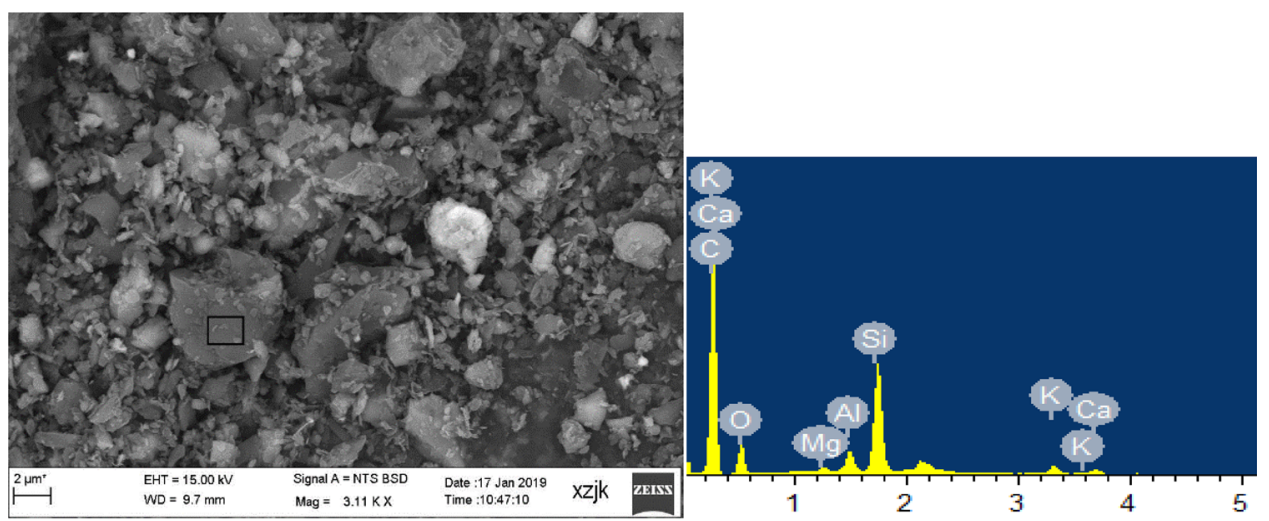

(a)
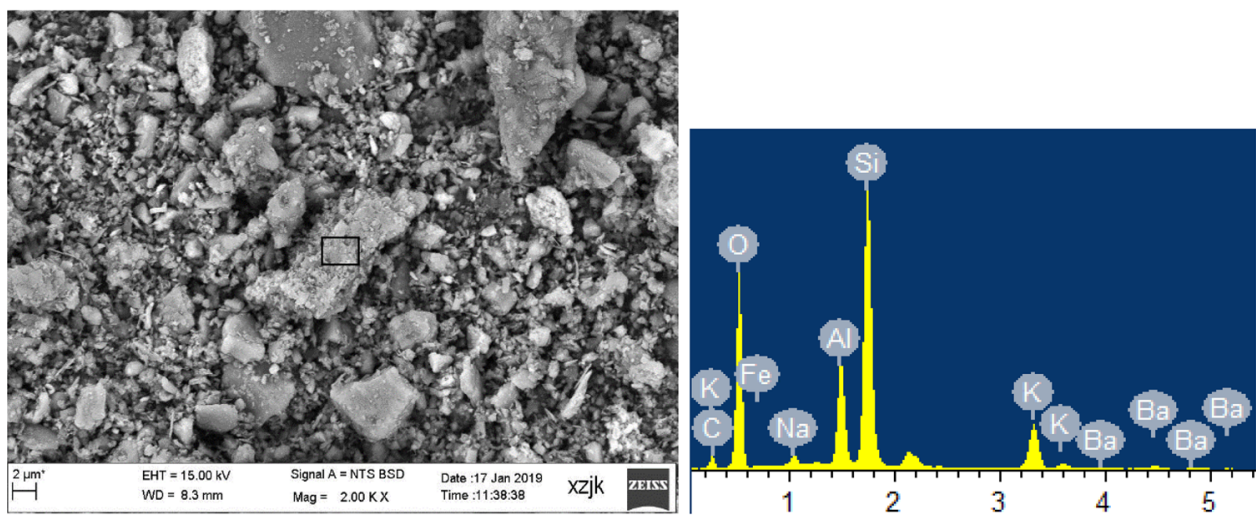

(b)

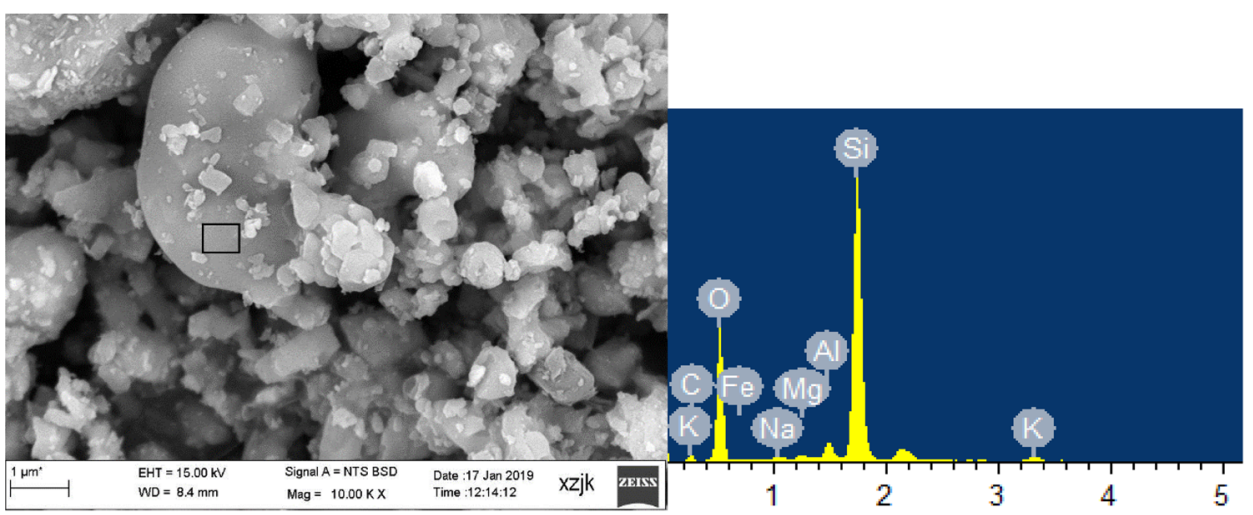

(c)

Fig. 3 SEM images and mineral components of a raw stone coal, b coal ash heated at $600{ }^{\circ} \mathrm{C}$, and $\mathbf{c}$ coal ash heated at $1000{ }^{\circ} \mathrm{C}$

decomposed and transferred at high temperature (Liu et al. 2003).

The exchangeable fractions of elements are associated with clay minerals, humic acids, and hydrated oxides of iron and manganese (Tessier et al. 1979). Heating promoted the transformation of $\mathrm{Cr}$ in stone coal from organic matter-bound $\mathrm{Cr}$ to exchangeable and carbonate-bound $\mathrm{Cr}$ at $600{ }^{\circ} \mathrm{C}$. The fraction of $\mathrm{Cr}$ associated with organic matter increased again in coal ash at $1000{ }^{\circ} \mathrm{C}$.
As for $\mathrm{Cr}$, the major forms of $\mathrm{Cd}$ were $\mathrm{Fe}-\mathrm{Mn}$-bound $\mathrm{Cd}$ in raw stone coal and carbonate- and $\mathrm{Fe}-\mathrm{Mn}$-bound $\mathrm{Cd}$ in coal ash heated at $600{ }^{\circ} \mathrm{C}$. However, at $1000{ }^{\circ} \mathrm{C}$, residual $\mathrm{Cd}$ was the primary form of $\mathrm{Cd}$ in coal ash. During combustion, the fraction of $\mathrm{Cd}$ associated with organic matter decreased, accounting for $1 \%-7 \%$ of total $\mathrm{Cd}$, while the fraction of residual $\mathrm{Cd}$ increased significantly from $8 \%$ to $55 \%$. Similarly, in past studies, carbonates and monosulfides were the dominant fractions of $\mathrm{Cd}$ in stone coal, while only a small amount of $\mathrm{Cd}$ was associated with organic and 


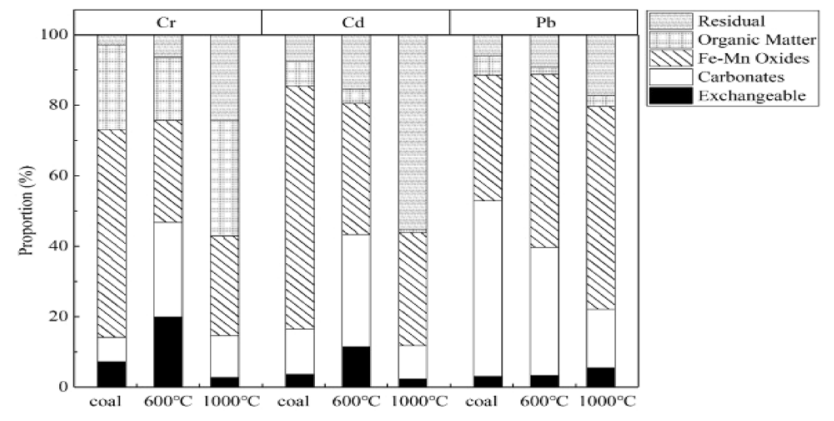

Fig. 4 Proportions of different forms of $\mathrm{Cr}, \mathrm{Cd}$, and $\mathrm{Pb}$ in the raw stone coal and its combustion ash generated at $600{ }^{\circ} \mathrm{C}$ and $1000{ }^{\circ} \mathrm{C}$

insoluble matter (Robert et al. 2018; Xiong et al. 2017). Finkelman (1981a, b) and Swaine (1990) concluded that the majority of cadmium in coal is associated with sphalerite as shielded sulfides. The burning process increased the residual fraction of $\mathrm{Cd}$ in this study; however, the $\mathrm{EF}$ of $\mathrm{Cd}$ at $1000{ }^{\circ} \mathrm{C}$ was only 0.50 , indicating that $\mathrm{Pb}$ was more volatile than chromium and cadmium during the combustion of stone coal; thus, lead would be released to the atmosphere, resulting in risks to human life.

In this study, substantial amounts of lead were present as carbonate forms (50\% of total lead) and Fe-Mn-bound forms $(36 \%$ of total lead), while the fractions of exchangeable, organic matter-bound, and residual lead were small. The results are similar with previous findings. Finkelman (1981a, b) reported that the dominant form of lead in most coals was galena with some lead occurring in sulfates, carbonates, phosphates, and silicates, especially in sulfide-poor coals. Swaine (1990) suggested that lead may occur as pyrite or as organic-associated forms in low-rank coals. Robert et al. (2018) found that in bituminous coal, only a small amount $(5 \%-10 \%)$ of lead was associated with silicates (Robert et al. 2018).

Burning the stone coal changed the forms of $\mathrm{Pb}$ present in the coal ash, as for $\mathrm{Cr}$ and $\mathrm{Cd}$. For example, the Fe-Mnbound and residual lead fractions in coal ash increased notably with increasing combustion temperature. The $\mathrm{Fe}-$ Mn-bound forms accounted for $49 \%$ of total lead at $600{ }^{\circ} \mathrm{C}$ and $58 \%$ at $1000{ }^{\circ} \mathrm{C}$. In contrast, the fraction of $\mathrm{Pb}$ associated with carbonates decreased, while the small fractions of organic matter-bound and exchangeable $\mathrm{Pb}$ in stone coal did not change noticeably. This further verified that coal combustion transformed the forms of $\mathrm{Pb}$ found in stone coal by changing the mineral structure and composition.

\section{Conclusions}

This study investigated the enrichment, occurrence, and migration of chromium, cadmium, and lead in stone coal and coal ash from the southern area of Shaanxi province,
China. Compared with other Chinese coals, the stone coal from the study area was enriched in $\mathrm{Cr}, \mathrm{Cd}$, and $\mathrm{Pb}$. As the combustion temperature increased, the contents of $\mathrm{Cr}, \mathrm{Cd}$, and $\mathrm{Pb}$ first increased (at temperatures below $600{ }^{\circ} \mathrm{C}$ ) due to the burning of organic matter followed by volatilization at higher temperatures (above $700{ }^{\circ} \mathrm{C}$ ) due to the decomposition of clay minerals (e.g., kaolinites and illites). The dominant forms of occurrence of the heavy metals in stone coal were $\mathrm{Fe}-\mathrm{Mn}$-bound forms for $\mathrm{Cr}$ and $\mathrm{Cd}$ and carbonates for $\mathrm{Pb}$. The forms of occurrence of $\mathrm{Cr}, \mathrm{Cd}$, and $\mathrm{Pb}$ changed with combustion temperature. Upon combustion, the residual fractions of $\mathrm{Cr}, \mathrm{Cd}$, and $\mathrm{Pb}$ all increased, and the dominant forms in coal ash were $\mathrm{Fe}-\mathrm{Mn}$ oxides, organic matter, and residual forms for $\mathrm{Cr}$, residual forms for $\mathrm{Cd}$, and $\mathrm{Fe}-\mathrm{Mn}$ oxides for $\mathrm{Pb}$. The combustion of the studied stone coal could release hazardous elements to the atmosphere via fly ash from the power plant. This is particularly true for $\mathrm{Cd}$, for which almost half of the total amount was released. This release of hazardous elements would pollute the soil and crops and pose a risk to public health.

Acknowledgements This research was supported by the National Natural Science Foundation of China (No. 41572218).

\section{Compliance with ethical standards}

Conflict of interest The authors declare no conflict of interest.

Open Access This article is distributed under the terms of the Creative Commons Attribution 4.0 International License (http://crea tivecommons.org/licenses/by/4.0/), which permits unrestricted use, distribution, and reproduction in any medium, provided you give appropriate credit to the original author(s) and the source, provide a link to the Creative Commons license, and indicate if changes were made.

\section{References}

Bai XF (2003) The distributions, modes of occurrence and volatility of trace elements in coals of China. Doctor's Thesis, Beijing: Coal Science Research Institute

Chen J, Wey MY, Liu Z (2001) Adsorption mechanism of heavy metals on sorbents during incineration. J Environ Eng 127:63-69

Chen ZG, Wu JQ, Yu Q, Xu MH (2013) Investigation on combustion and leaching characteristics of trace element Se of Enshi stone coal. J Huazhong Univ Sci Technol (Nat Sci Edit) 41:125-128

Cheng P (2001) The quality, classification and utilization of coal in China. Chemistry Industry Press, Beijing, pp 35-40

Chu SJ, Zhang J (2014) Latest development and prospect of process for utilizing stone coal. Ferro-Alloys 3:60-64

Cutruneo CMNL, Oliveira MLS, Ward CR, Hower JC, Brum ISA, Sampaio CH, Kautzaman RM, Taffarel SR, Teixeira EC, Silva LFO (2014) A mineralogical and geochemical study of three Brazilian coal cleaning rejects: demonstration of electron beam applications. Int J Coal Geol 130:33-52

Dai SF, Ren DY, Chou CL, Finkelman RB, Seredin VV, Zhou YP (2012) Geochemistry of trace elements in Chinese coals: a 
review of abundances, genetic types, impacts on human health, and industrial utilization. Int $\mathrm{J}$ Coal Geol 94:3-21

Dai SF, Seredin VV, Ward CR, Jiang JH, Hower JC, Song XL, Jiang YF, Wang XB, Gornostaeva T, Li X, Liu HD, Du ML, Yang ZY, Fan JW, Mi JC (2017) Study on geochemical characteristics and significance of associated elements of stone coal in Zhenping, South Shaanxi. China Coal 43(06):37-41

Du M, Yang Z, Fan J, Mi J (2017) The geochemical characteristics and significance of the associated elements of Zhenping stone in southern Shaanxi. China Coal 43(6):37-41

Erarslan C, Örgün Y (2017) Mineralogical and geochemical characteristics of coal ash from the Northwest Thrace region, Turkey: a case study. Arab J Geosci 10:1-16

Finkelman RB (1981a) The origin, occurrence, and distribution of the inorganic constituents in low-rank coals. In: Proceedings of the basic coal science workshop. H.H. Schobert, compiler. Grand Forks Energy Tech, Center, Grand Forks, ND, pp 70-90

Finkelman RB (1981b) Modes of occurrence of trace elements in coal. In: USGS Open-File Report 81-99: 322

Finkelman RB (2005) Modes of occurrence of environmentallysensitive trace elements of coal. Environ Asp Trace Elem Coal 5:24-50

Gentzis T, Goodarzi F (2000) Effect of geological processes on coal quality and utilization potential: review with examples from western Canada. J Hazard Mater 74(1/2):109-124

Jia Z (2014) Geological characteristics of the stone coal belt in Haoping, Ankang City. Value Eng 30:310-311

Ketris MP, Yudovich YE (2009) Estimations of clarkes for carbonaceous biolithes: world averages for trace element contents in black shales and coals. Int J Coal Geol 78:135-148

Li LY, Ye JD, Zhang L, Wu ZM, Wan ZY (2005) The survey of status quo on heavy-metal contamination and utilization in the bone-coal mining. Energy Environ Prot 19:58-61

Li LY, Tang Q, Zheng LG, Liu X, Chu AX (2018) Migration and volatilization of chromium in coal under different combustion temperatures. Environ Chem 37:437-444

Liu YJ (1984) Element geochemistry. Science Press, Beijing, pp 80-86

Liu GJ, Yang P, Yu GM, Peng ZC (2003) Relationship between volatilization of hazardous trace elements and their occurrences and combustion temperatures during coal combustion. J Combust Sci Technol 9:6-10

Liu HM, Pan W, Wang CB, Zhang Y (2016a) Volatilization of arsenic during coal combustion based on isothermal thermogravimetric analysis at $600-1500{ }^{\circ} \mathrm{C}$. Energy Fuels 30:6790-6798

Liu ZX, Dai HZ, Liu J, Ge Z (2016b) Suggestions and current situation of exploration, development and utilization of stonecoal resources in China. China Min 25:18-21

Luo KL, Su WZ, Du ML, Lei FY (1995) Some microelements of lower paleozoic stone coal in South Qinling. J Xi' an Min Inst 15:131-135

Mao D, Zheng B, Yan W (1999) Preliminary report on the investigation of trace elements in the outcropping area of stone coal in Enshi State, Hubei province, China. J Prev Med 10(2): $1-2$

Martinello K, Oliveira MLS, Molossi FA, Ramos CG, Teixeira EC, Kantzmann RM, Silvs LFO (2014) Direct identification of hazardous elements in ultra-fine and nanominerals from coal fly ash produced during diesel cofiring. Sci Total Environ 470-471:444-452

Mei J (1994) Trace element behavior in coal-fired power plants. Fuel Process Technol 39(1-3):199-217

Oliveira MLS, Marostega F, Taffarel SR, Saikia BK, Waanders FB, Daboit K, Baruah BP, Silva LFO (2014) Nano-mineralogical investigation of coal and fly ashes from coal-based captive power plant (India): an introduction of occupational health hazards. Sci Total Environ 468-469:1128-1137

Robert B, Finkelman RB, Curtis A (2018) Quantification of the modes of occurrence of 42 elements in coal. Int $\mathrm{J}$ Coal Geol 185:138-160

Saikia BK, Ward CR, Oliveira MLS, Hower JC, Baruah BP, Braga M, Silva LF (2014) Geochemistry and nano-mineralogy of two medium-sulfur northeast Indian coals. Int J Coal Geol 121:26-34

Shi Y, Wu C (2016) Emission characteristics of $\mathrm{Pb}$ in coal-fired plants research development. Therm Power Gener 45:1-8

Silva LFO, Moreno T, Querol X (2009a) An introductory TEM study of fenanominerals within coal fly ash. Sci Total Environ 407:4972-4974

Silva LFO, Oliveira MLS, Boit KM, Finkelman RB (2009b) Characterization of Santa Catarina (Brazil) coal with respect to human health and environmental concerns. Environ Geochem Health 31:475-485

Swaine DJ (1990) Trace elements in coal. Butterworths, London, p 278

Swaine DJ (2013) Trace elements in coal. Butterworths Heinemann, London, pp 43-45

Swaine DJ, Goodarzi F (1995) Environmental aspects of trace elements in coal. Energy Environ 2(1):2

Tang Q, Sheng W, Li LY, Zhang LG, Miao CH, Sun RY (2018) Alteration behavior of mineral structure and hazardous elements during combustion of coal from a power plant at Huainan, Anhui, China. Environ Pollut 239:768-776

Tessier A, Campbell PGC, Bisson M (1979) Sequential extraction procedure for the speciation of particulate trace metals. Anal Chem 51:844-851

Uberoi M, Shadman F (1990) Sorbents for removal of lead compounds from hot flue gases. AIChE J 36:307-309

Vassallo AM, Cole-Clarke PA, Pang LSK, Palmisano AJ (1992) Infrared emission spectroscopy of coal minerals and their thermal transformations. Appl Spectrosc 46:73-78

Vassilev SV, Vassileva CG, Karayigit AI, Bulut Y, Alastuey A, Querol X (2005) Phase-mineral and chemical composition of composite samples from feed coals, bottom ashes and fly ashes at the Soma power station, Turkey. Int J Coal Geol 61:35-63

Vassileva CG, Vassilev SV (2006) Behaviour of inorganic matter during heating of Bulgariancoals 2. Subbituminous and bituminous coals. Fuel Process Technol 87:1095-1116

Wang X, Yao DX, Feng QY (2013) Distribution characteristics and environmental impact of heavy metals during lignite combustion. Acta Sci Circumst 33:1389-1395

Wen MZ, Xu WD (2010) Mobility and release of hazardous trace elements in coal-fired power plant. J China Coal Soc 35(9):1518-1523

Xiong Y, Xiao TF, Liu YZ, Zhu JM, Ming ZP, Xiao QX (2017) Occurrence and mobility of toxic elements in coals from endemic fluorosis areas in the Three Gorges Region, SW China. Ecotoxicol Environ Saf 144:1-10

$\mathrm{Xu} \mathrm{YJ}$ (2004) Study on the reaction mechanism of trace element $\mathrm{Pb}$ in the coal combustion process Master's Thesis, Huazhong University of Science \& Technology

Yao DX, Zhi XC, Zheng BS (2002) Research overview of trace elements release in coal combustion process. J Hefei Univ Technol 25(3):373-378

Yu LY, Lu JD, Wu G, Feng W, Chen W, Shen K (2004) Research on the morphology and distribution of trace heavy metals during coal combustion. Power Eng 24:640-645

Zhang JY, Ren DY, Wang YQ, Zhao FH, Xu DW (2000) Relationship between organic trace elements in coals and the coal rank. Coal Geol Explor 28(06):11-13 